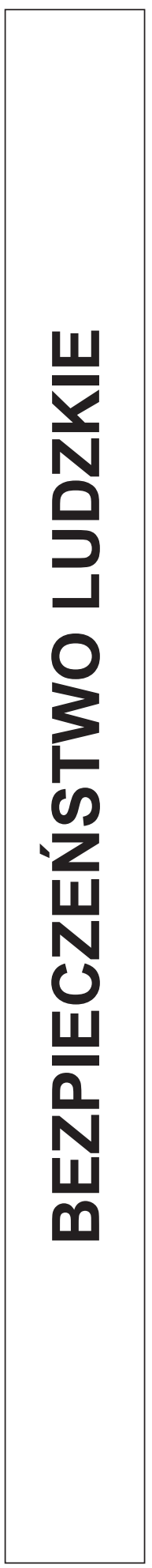





\title{
REFUGEE QUESTION AS AN INTERNATIONAL GLOBAL PROBLEM
}

\begin{abstract}
Refugeeism - a phenomenon characteristic of contemporary international relations - occurs when a person "owing to well-founded fear of being persecuted for reasons of race, religion, nationality, membership of a particular social group or political opinion, is outside the country of his nationality" (or former habitual residence in the case of a person not having a nationality) "and is unable or, owing to such fear, is unwilling to avail himself of the protection of that country" (or is unwilling to return to the country of former habitual residence) (Convention, 1951: Art. 1A). Refugeeism can also take the form of mass relocations, especially in the face of military conflicts or general breaching of human rights. The number of individuals forced to leave their places of residence due to persecution was estimated at nearly forty million in 2013. The purpose of this paper is to present the refugee question as an international global problem that may appear in any region of the world, impacting the situation of states and societies, that is perceived as both a threat and a fundamental challenge for the entire international community.
\end{abstract}

\section{REFUGEE QUESTION IN THE CONTEXT OF MIGRATION}

The concept of migration encompasses all population relocations of both permanent and semipermanent nature. It is defined as "a permanent or semipermanent change of residence" (Lee, 1966: 49). The phenomenon of migration is the subject of interest for many academic fields, ranging from demography, through sociology and political science to history and economic science. Migration research conducted by the representatives of various academic fields has resulted in the emergence of different migration theories in order to explain this phenomenon.

The first systematic theory of migration was provided by Ernest George Ravenstein. It encompasses eleven laws concerning the reasons for migration (Revenstein, 1885: 198 and subs.). As Castels and Miller point out "[a]n important role in migration studies was played by neoclassical theory, which is the dominating paradigm in economics" (Castels, Miller, 2011: 41) but is also taken into account in sociology, demography and geography. Neoclassical theory identifies economic inequalities between different areas as the factor that triggers migratory flows. Persons are more prone to migrate when the destination area offers high opportunities for satisfactory remuneration while adaptation costs are low. Therefore, the essential categories are utility and maximum profit. Yet this approach is founded on the frequently erroneous assumption that potential mi- 
grants have exhaustive knowledge about income levels and employment opportunities in the destination area. Another weakness of neoclassical theory lies in the fact that it studies migration processes only with respect to educated individuals who are attractive to the target state, whereas contemporary migration practice shows that it is mainly uneducated people who migrate most often, who do not stand a chance of achieving prosperity in their state of origin, but who do not stand a chance of being legally admitted by the receiving state, either. Migration processes may be triggered not only by the lack of prosperity potential in the state/region of origin, but also by natural disasters posing a threat to human existence. The decision to migrate may therefore stem not so much from the intention to maximize profit but rather to minimize risk (or to attempt to survive), as pointed out by the representatives of the new economics of labor migration (or new economics of migration). They argue for perceiving migration as a group rather than an individual phenomenon. They stress that the decision to migrate is rarely made individually, but rather in a circle of a family or local community, and it depends on a family situation and the status of an individual in a group (Stark, Bloom, 1985). This decision becomes a kind of contract, binding a migrant and his family, while the expenses and benefits of migration are experienced by both a group and an individual. The advocates of this approach reject migration as the outcome of an independent decision made by a migrant. They argue for this phenomenon to be perceived in terms of mutual interdependence between a migrant and a group. Consequently, they view "migration as a 'calculated strategy' and not as an act desperation or boundless optimism" (ibidem: 174).

The dual labor market theory stresses the large number of factors that are conducive to migration. According to this theory, migration is caused by "a chronic and unavoidable need for foreign workers" in receiving countries (Massey et al., 1993: 440-441) and a virtually unlimited migratory potential in underdeveloped or developing economies. There is a primary and secondary market in every economy. The former one is stable, offers high pay, good labor conditions and opportunities for career advancement. The latter offers jobs of low social prestige, failing to ensure a sense of stability, opportunities for promotion and pay rises. Therefore, the citizens of a given country are not interested in being employed in such sectors, and the resulting gap is filled by foreigners. By this token, the incoming foreigners are in no way competition to the citizens of receiving countries. From the point of view of this theory, migration is merely a market instrument, taken advantage of by the employers and governments of receiving countries.

One of the most popular sociological theories is the migration networks theory, which claims that the decisions to relocate result from interpersonal contacts between returnees and those contemplating migration. The former are a source of information about the benefits and costs of migration, they can offer experience and assistance, similar to the migrants who continue their stay in third countries. By this token, migration networks of interpersonal ties (frequently based on family and friendship relations) emerges "that connect migrants, former migrants and nonmigrants in origin and destination areas." Such ties are the factors that influence migration decisions, increase mobility, stimulate interest in migration to certain states or regions, but first and foremost "they lower the costs and risks of movement" (ibidem: 448-449). This peculiar migra- 
tion chain allows the directions of relocation to be forecasted. This approach does not take economic factors into account, though, and does not explain the reasons for primary migration.

The social equilibrium theory can play a complementary role. This theory approaches migration as a product of population pressure, that is the discrepancy between a person's expectations and their actual situation. The lack of opportunities for persons to satisfy their needs and achieve their goals in their place of residence prompts the decision to relocate. Migration to another territory or state gives a chance of finding a more advantageous location in economic or social terms.

The migration systems theory originates from geography and it assumes that migrants move between two or more states. These usually are states from the same geographical region, although migration can encompass remote states as well. This is not about geographical vicinity but rather about ties of a historical (such as those resulting from the colonist period), political (old alliances, past conflicts), economic (trade exchange, investments) and cultural character. This approach focuses on the analysis of "both 'ends' of migration flow and researching all ties between the countries involved in the flow of migrants" (Castels, Miller, 2011: 47). It should be observed that migration systems are not permanent in nature. A change of political or economic circumstances, whether it occurs inside this system or in its external surroundings, results in its evolution. Consequently, states (elements) can either join the system or leave it, for instance, as a result of an international conflict, civil war, or an economic crisis. Alterations can also be observed with reference to the interactions between the elements of the system, as well as the features of these elements. All this can result in changes in migration flows. The systems approach is criticized for its lack of references to personal factors triggering migration.

Differences in the development of states are taken into account by the dependency theory, which does not approach migration as a mean to achieve development (both in its individual and national dimensions) and improved living conditions of these who relocate, but as the reason for underdevelopment. The proponents of this approach believe that migration devastates agricultural communities, diminishes their significance and uproots their population, leading to a brain drain. The main focus here is on the analysis of negative outcomes of migration for the areas of origin, which is concluded in the statement that the development of underdevelopment is the fundamental outcome. A more complex World systems theory does not refer directly to migration but allows it to be perceived as "a natural outgrowth of disruptions and dislocations that inevitably occur in the process of capitalist development" (Massey et al., 1993: 445), and in modern times - as the outcome of globalization processes. When states are classified in terms of degree of development into core, semi-peripheral, peripheral and isolated nations, migration is perceived as a mechanism shaping the domination of economies of centrally located states. Nevertheless, this theory neglects such factors as differing pay levels, labor conditions or the unemployment level, and focuses on macroeconomic differences. Consequently, it is concluded that the migratory behaviors of the inhabitants of countries at different levels of development vary, and the tendency for illegal migration is associated with the inhabitants of peripheries. This theoretical approach has a shortcoming, though, as it perceives migration solely as relocation from less developed countries 
to better developed ones. It does not provide an explanation for migrating between countries at comparable development levels. It also fails to account for the long-standing failure of migratory policies implemented by developed countries (ibidem).

In order to understand the nature of migration as a phenomenon, and exhaustively demonstrate its determining factors, properties, course and consequences in its individual and national, regional and global dimensions, an interdisciplinary approach is necessary. The literature on the subject enumerates different typologies of migration, but due to the subject of this analysis it is essential to define forced migration, including refugeeism.

The basic typology that should be referred to, involves the division of migration into external and internal. The former concerns crossing state borders, whereas the latter encompasses migratory movements that occur within a state. This classification is essential for political science, and in particular for international relations. Both focus in particular on external migration and its influence on the internal relations within a state, as well as relations between states and the other actors on the international stage.

As regards the quantitative criterion, individual, group and mass migration can be identified.

The legal criterion divides migration into legal and illegal. The former is defined as the lawful (in terms of domestic and international law, and should the division concern the European Union - also European law) crossing of state borders and lawful stay on the territory of another state. This means that an individual who migrates to another state meets all legally stipulated conditions for departure and a short-, or long-term stay abroad. This means that an individual is in possession of the necessary documents, crosses the border at a designated place, that the actual purpose of his stay in the receiving country conforms to the purpose declared and he does not breach the law. In contrast, illegal migration is characterized by crossing the border in contravention of a given state's law, by entering it in an illicit place or using forged documents. Illegal migration also covers cases of staying in a third state in violation of domestic law, for instance by remaining in the country after the expiry of the date indicated in the immigration decision, or staying for purposes other than those indicated when entering this state.

In terms of the manner (or degree) of organization, organized and non-organized migration can be distinguished. The latter occurs as a result of an impromptu, spontaneous decision to migrate (Jończy, 2003: 12; Niedźwiecki, 2010: 25).

With respect to the criterion of duration, permanent and temporary - short-, and long-term - migration can be identified. Permanent (unlimited) migration is usually performed with the intention of settling down in another area and concentrating all activities there. For this reason it is also called settlement migration. As regards short-, and long-term migration it is divided into those of greater or less than twelve months duration. Short-term migration is seasonal, related to migrants' stay in receiving areas for certain parts of the year, or circulatory migration, when people move between certain areas (or states) many times during the year. Short-term migration does not refer, however, to business trips, tourist trips, travel made for the purposes of medical treatment or university study, or recreational visits.

The most inexact criterion for division with respect to migration is the indicator of its causes. Taking this criterion into consideration frequently results in a variety of 
sometimes opaque classifications that distinguish, for instance; (1) economic, political and other migration (Maryański, 1984: 8-9); (2) economic and non-economic, that is family-related, partner-related, religious, tourist, health, patriotic, national, political, and ecological migration (Adamczyk, 2012: 33); (3) labor-related, family-related, subordinated, matrimonial-related, political, religious, national, ecological and individual migration (Knopek, 2008: 23). When analyzing migration one needs to refer to its causes, but it is not necessary to multiply the various classifications that frequently are artificial. It is justified here to refer to Everett S. Lee's concept of four "factors in the act of migration": (1) associated with the area of origin; (2) associated with the area of destination; (3) intervening obstacles; (4) personal factors (Lee, 1966: 49-50). This concept particularly accounts for the existence of pull-push factors. The former are certain incentives provided by the receiving state, such as the opportunity for legal employment, sometimes even guaranteed employment, higher pay, obtaining and advancement of professional qualifications, social support, and assistance in the integration with the community of the receiving state. Among push factors there are the poor economic and/or social situation in the country of origin, and - particularly in the case of undemocratic states - persecution of a political, racial, national, or religious nature, or related to being a member of a certain social group, as well as the threat to life or health as a result of armed conflicts or natural catastrophes. Apart from the factors indicated above, there are also intervening obstacles that determine migration. "These include, among other things, obstacles resulting from cultural differences, distance and the consequent travelling costs" (Sakson, 2008: 13) as well as restrictive instruments of immigration policies of certain states. Taking these three factors into consideration leads to the conclusion that the number of individuals relocating to the destination area is directly proportional to the number of push factors in the area of origin and pull factors, that is the opportunities available in the destination areas, while it is inversely proportional to the indirect obstacles in the destination areas (Stouffer, 1940: 846). Personal factors (such as momentary emotions, for example, a sense of threat) should not be ignored, as they also influence decisions to relocate. "The decision to migrate, therefore, is never completely rational, and for some persons the rational component is much less than the irrational" (Lee, 1966: 51).

Experts from the World Bank have attempted to comprehensively understand the pull-push factors which determine relocation decisions (Tab. 1).

Table 1

Motivations for Migration according to the World Bank

\begin{tabular}{||l|l|l||}
\hline \hline \multicolumn{1}{|c|}{ Push factors } & \multicolumn{1}{|c||}{ Pull factors } \\
\hline $\begin{array}{l}\text { Economic and } \\
\text { demographic }\end{array}$ & $\begin{array}{l}\text { poverty, unemployment, low wages, high fer- } \\
\text { tility rates, lack of basic health and education }\end{array}$ & $\begin{array}{l}\text { prospects of higher wages, potential for im- } \\
\text { proved standard of living, personal or profes- } \\
\text { sional development }\end{array}$ \\
\hline Political & $\begin{array}{l}\text { conflict, insecurity, violence, poor gover- } \\
\text { nance, corruption, human rights abuses }\end{array}$ & safety and security, political freedom \\
\hline $\begin{array}{l}\text { Social and } \\
\text { cultural }\end{array}$ & $\begin{array}{l}\text { discrimination based on ethnicity, gender, reli- } \\
\text { gion, and the like }\end{array}$ & $\begin{array}{l}\text { family reunification, ethnic (diaspora migra- } \\
\text { tion) homeland, freedom from discrimination }\end{array}$ \\
\hline
\end{tabular}

Source: Migration and Remittances. Eastern Europe and the Former Soviet Union, (eds.) A. Mansoor, B. Quillin, Washington 2007, p. 78. 
Whereas the classification of the pull-push factors is accurate, the description of the nature of some raises doubts. Firstly, human rights abuses have been classified as a push factor of a political character, while discrimination is among push factors of a social and cultural character. Discrimination is clearly political in nature, though. Regardless of the reasons for persecution, be it national or ethnic origin, religion or sex - discrimination constitutes the breaching of human rights, which is frequently of a fundamental character. Similarly, freedom from discrimination should be regarded as a pull factor of a political character, not of a social and cultural character. Another observation that needs to be made, as concerns the classification suggested by the World Bank experts, is related to their viewing health and education as economic factors. While the level of education and the guaranties of adequate health care do influence an individual's economic situation, their dimension is primarily social. The rights to education (at least the elementary level) and to broadly understood social care are classified in the international law on human rights as social and cultural rights. The final reservation concerns personal development regarded as a push factor of economic character. Personal development can clearly improve labor market opportunities, for instance by raising a person's qualifications and developing skills, but it should then be termed as professional development. The notion of 'personal development' primarily concerns social and cultural dimensions and is determined by the access to culture and education, among other things. Therefore, it is necessary to develop an alternative division of factors determining migration (Tab. 2).

Table 2

Factors determining migration

\begin{tabular}{||l|l|l||}
\hline \hline Economic & \multicolumn{1}{|c|}{ Push factors } & \multicolumn{1}{|c|}{ Pull factors } \\
\hline poverty, unemployment, low wages, high fertil- & $\begin{array}{l}\text { prospects of higher wages, potential for im- } \\
\text { proved standard of living, professional develop- } \\
\text { ment }\end{array}$ \\
\hline Political & $\begin{array}{l}\text { conflict, insecurity, violence, poor governance, } \\
\text { corruption, human rights abuses, discrimination } \\
\text { based on nationality, ethnicity, race, religion, } \\
\text { political opinion, gender, or membership of a so- } \\
\text { cial group }\end{array}$ & $\begin{array}{l}\text { safety and security, political freedom, obser- } \\
\text { doms, freedom from discrimination }\end{array}$ \\
\hline $\begin{array}{l}\text { Social and } \\
\text { cultural }\end{array}$ & $\begin{array}{l}\text { high fertility rates, lack or low social care, lack } \\
\text { or low standard of education }\end{array}$ & $\begin{array}{l}\text { family reunification, ethnic (diaspora migra- } \\
\text { tion) homeland, personal development }\end{array}$ \\
\hline \hline
\end{tabular}

Source: Author's own concept.

For the purposes of this analysis, it is crucial to divide migration in terms of the criterion of the freedom of decision allowing voluntary and involuntary migration to be distinguished. The latter can take two forms. One is forced migration which can be defined as changes in the place of residence caused by the prescriptive or restrictive activity of national authorities (Kraszewski, 2003: 13). This is direct coercion, that is inspired politically, racially, nationally, religiously, or socially. It is worth noting that coercion does not necessarily have to result from human activities. There may occur the so-called situational coercion, resulting in a decision to migrate "under the circumstances that threaten one's biological or social existence" (Kersten, 1996: 21). This can 
be exemplified with population relocation due to natural disasters and damage to the natural environment, which is currently termed eco-refugeeism. In this case one can follow the line taken by W. Petersen and talk about impelled migration: "when the migrants retain some power to decide wether or not to leave" (Petersen, 1958: 261).

As considered in this paper, refugeeism is therefore understood as forced migration. Such migration can assume the form of expulsion, displacement, deportation or resettlement (Kersten, 1996: 18-19). Expulsion (Vertreibung) covers activities aimed at removing an individual or community (who are perceived as undesirable) from a given territory. Such activities can be undertaken by the authorities, or can result from bottom-top initiatives. Displacement (Aussiedlungen) is an organized activity, where direct coercion is applied to a certain community. It is of no importance whether this displacement is effected by virtue of international agreements or follows from a unilateral decision of state authorities, or whether it concerns the state's citizens or citizens of another state (ibidem). Deportation can concern both communities and individuals and constitutes an act of direct coercion performed by authorities of a given state. An individual or a group is sent to a location determined in advance, such as a state of nationality, of permanent residence, or a third state through the territory of which a person concerned had travelled. Deportation is usually exercised with respect to foreigners who fail to meet the conditions of legal stay in a given country. It most frequently concerns foreigners who crossed the border illegally, or whose stay in that country violates its law. In order to distinguish resettlement (Umsiedlungen) as a migratory movement calls for an analysis of the "coercion function, the relation between the resettler and organizer of migration, and, finally, of the scope of activities a given process involves" (ibidem: 19). Resettlement is a coercive type of migratory movement involving permanent settlement in another area. ${ }^{1}$

The typology above does not include the fifth, essential form of forced migration, namely refugeeism. In this case one deals with a decision made by a person (or a group) who, due to a threat to life, health or freedom, decides to leave place of residence and seek shelter in another area. In the classic sense, for refugeeism to occur requires that state borders are crossed and protection is sought in another country which is neither a country of nationality or permanent residence. At present, however, refugeeism can also take the form of internal displacement, where protection is sought in another part of a state of origin. Internal displacement is typically caused by persecution that occurs only in a part of a state. It is frequently related to a situation where it is impossible to cross national borders, thereby resulting in the need to seek shelter in other regions of such a state.

Applying the above findings (namely, the theoretical approaches and classifications) to the question of refugees, one must state that this kind of relocation is:

- political, resulting from fear of persecution, sense of threat to one's own life and the lives of loved ones;

- individual, group or mass, as persecutions can affect a certain individual (for instance a dissident), communities that differ in terms of nationality, ethnicity, race, religion,

${ }^{1}$ Resettlement can also be voluntary, when resettlers consent to change their place of residence and thus can take an active part in this process. 
or even social groups, but also in the face of armed conflicts, refugeeism frequently becomes a mass phenomenon;

- external, where the borders of a state of nationality or permanent residence are crossed and protection is sought in a third state; at present, however, more and more frequently internal displacements can be observed, where the oppressed move around within a territory of a state of origin;

- seasonal in nature, and concluded once the circumstances that caused the refugeeism cease; protracted refugee situations can also be observed, however, when a given individual cannot safely return to his own country and enjoys refugee status to the end of his life - an individual refugee case can then be classified as permanent relocation;

- simultaneously legal and illegal; legal when a refugee crosses a border in conformity with legal regulations of a hosting state, but even then leaving his own country can breach this state's internal law (which is particularly the case of undemocratic states, where the right to leave the country is restricted); in case of mass refugeeism the arrival in a host state frequently does not meet conditions of being legal as refugees cross borders without the necessary documents, or through the so-called green (land) or blue (sea) border (which is prohibited);

- usually organized in individual cases and unorganized when mass movements are concerned;

- involuntary, coerced, as demonstrated above.

\section{THE GLOBAL NATURE OF THE PHENOMENON}

On account of all the reasons discussed above, refugeeism has attracted the interest of the international community, which considers this question to constitute a global problem.

Interest in global problems could be noted as early as the $19^{\text {th }}$ century, when it was related to the emerging adverse outcomes of the industrial revolution and the positive results of scientific progress (Cesarz, 2002: 13). Another significant factor at that time involved the development of a new kind of international relations, which resulted in the processes gradually becoming universal. International turnover covered the whole world geographically, international organizations emerged as the manifestations of initiatives aimed at tighter cooperation in order to solve common problems, the leading role of international law in shaping international relations was stressed, public opinion began to have more influence on decisions (also international ones) (ibidem). Consequently, the problems that individual countries used to struggle with became international issues involving all the members of the international community in solving them. This trend further intensified at the turn of the 1960s as a result of the increasing developmental gap between the North and the South, intensified arms race, deteriorating environmental situation, as well as oil and food crises whose aftermath could be experienced globally.

The notion of 'global problems' itself was propagated by the Club of Rome, established in 1968 on the initiative of A. King and A. Peccei. The purpose was to discuss the global dimension of the problems of the modern world and the need to take determined 
international steps in these respects. Experts from the Club of Rome characterized global problems in the following manner: (1) their worldwide range or influence and occurrence in all states irrespective of political and social differences; (2) their complex nature and multifariousness depending on social, economic or political factors; and (3) their mutual interactions and links (Meadows et al., 1972). Representatives of different academic fields, including political science and international relations, sociology and economics, have made attempts at defining and classifying global problems. The most significant feature of global problems was assumed to refer to their universal character - a given phenomenon becomes a global problem when it significantly concerns nearly all members of international community. Another important indicator of global problems has been their complexity, which differentiates them from other questions of international nature. It has also been considered justified to stress the long-term span of global problems, as they persist for a long time and frequently intensify and affect new areas, which, consequently, makes them impossible to be solved in a short period of time. Global problems are therefore characterized by a set of equal properties rather than by a single defined and decisive feature (Cesarz, 2002: 18). Consequently, one can follow the line taken by W. Anioł who identified three features that allow global problems to be distinguished: (1) they occur on a worldwide scale, concern the whole of humanity, to a greater or smaller degree influence all societies, and have a supra-national and supra-regional character; (2) their significance is enormous and they have the nature of critical threats or fundamental challenges; (3) cooperation and coordination of the activities of all members of the international community is necessary to solve global problems.

Although the features of global problems have been identified, it has been difficult to enumerate them in a distinct manner, which was noted by the representatives of the United Nations' member states. On December 3, 1968, in resolution 2398 (XXIII) the UN General Assembly obliged the UN Secretary-General to draw up an analysis of the global condition of the human environment and indicate the proposals for how to solve the most crucial threats. In the 1969 report prepared by an expert team, led by U. Thant, the following were identified as the symptoms of a global crisis encompassing all developed and developing states: (1) arms race and "little progress in disarmament;" (2) "growing disparities" in the level of development leading to problems with food and low level of education; (3) crisis of civilisation reflected in "dissatisfaction of youth with the establishment;" (4) ecological threats, such as devastation of arable land, increased urbanization and development of urban areas, insufficient coordination of advanced technology with the needs of the natural environment, increased danger of extinction of numerous plant and animal species; (5) the "population explosion;" (6) "disregard for human rights;" and (7) insufficient decolonization processes (Introduction, 1969: paras. 26, 28, 83, 86-90, 95, 133, 159). In The Limits to Growth Report of 1972, prepared for the Club of Rome, the global problems enumerated encompassed the questions of population decline, widespread pollution, decline in food and industrial production and depletion of natural resources. The second report, Mankind at the Turning Point, of 1974, indicated a demographic crisis resulting from the growing global population, disproportionate economic development and a food and energy crisis. In the third report for the Club of Rome of 1976 (Reshaping the International Or- 
der), ten issues were termed as global problems: weak international monetary system, unfair income distribution, low level of food production and the inappropriate division of this production, industrialization, inappropriate international labor division, unfair use of energy and natural resources, inappropriate management and use of marine resources, arms race, wrong direction of technological progress and technology transfer (Tinbergen, 1976). The 1977 report for the Club of Rome (Goals for Mankind) did not identify global problems, but rather global goals that were supposed to aid the implementation of the idea of humanization. The implementation of global goals was strictly related to the liquidation of global problems, though. The following were identified as four global goals: (1) security - in particular restraining the arms race and reducing the potential for international conflicts to break out; (2) production addressed at eliminating the specter of famine - in particular increased agricultural production and even distribution of food produced; (3) development aimed not at maximized economic growth but at meeting human material and spiritual needs; (4) rational usage of energy and natural resources (Goals, 1977). The No Limits to Learning Report, published two years later, emphasized that global problems had evolved, and encompassed not only material issues (such as poverty, demographic issues, problems related to protecting natural environment, as well as food, economy and energy problems) but also non-material issues, such as cultural identity, women's emancipation, children's status, access to information, and unemployment (Botkin, Elmandjra, Malitza, 1979: XV, 2, 5). Experts of the Independent Commission on International Development Issues (Brandt Commission), established in 1977 under the initiative of the World Bank, among the basic world issues included population issues leading to underdevelopment and poverty, famine and undernourishment, the problems of the natural environment and natural resources resulting in energy shortages, rapid urbanization which is harmful to the environment, and the development of technology which threatens human values. In their opinion, these problems were to be solved by the global community "taking bold initiatives" or "at least by global responsibility rooted in the experience of regional communities" (North-South, 1980: 13). During the Cold War, when the countries from the opposing blocs competed, experts called for the equal participation and commitment of all states in the struggle with global problems, instead of pursuing short-term particular interests. They suggested moving away from spending on armaments, undertaken by states not to guarantee security, but out of fear, and diverting the funds into development, enabling development problems to be eliminated. Similar conclusions were reached by the members of the Independent Commission on Disarmament and Security Issues (Palme Commission) (ibidem: 117, 121-122; Common Security, 1982: 8, 38). In the 1982 report prepared by G. Friedrich and A. Schaff, threats related to the saturation of the economy, science, commerce and medicine with microelectronic devices were indicated (Mojsiewicz, 2003: 11). The Bruntland report of 1987 stressed the importance of the United Nations for activities aimed at containing and eventually eliminating global problems. Those were catalogued as overpopulation, food security, endangered species and ecosystems, improper energy production and use, adverse impact of industry on the natural environment, and uncontrolled urbanization (Our Common, 1987: paras. 41-74). Four universal problems were additionally indicated: peace, security, development and the environment. The extant threat of a nuclear war, and political and military threats to 
state sovereignty were stressed, but primary attention was given to tense relations between states that possessed weapons of mass destruction (ibidem: paras. 86-88). In a 1983 report prepared by experts under the supervision of UN Secretary-General Javier Perez de Cuellar, the major problems of the world included development problems (poverty, economic and social inequalities) and international security (stressing disarmament and arms limitation, conflict control and conflict elimination), as well as the questions of "gross violations of human rights and restrictions of fundamental freedoms," especially racism, racial discrimination and refugeeism (Report, 1983: 1-3). A collective and 'fresh' approach to those problems was advised. In 1984, A. Peccei indicated over twenty issues considered as global problems (Peccei, 1994). Those included uncontrolled population growth, social differences and divisions, social injustice, famine and undernourishment, poverty, unemployment, growth mania, inflation, energy crisis, deficit of resources, disturbances in international trade and payments, protectionism, illiteracy and lack of educational reforms, youth revolt, alienation, sense of instability, uncontrolled urbanization and deterioration of towns, crime and drug addiction, police brutality, torture and terrorism, contempt for law and order, the nuclear threat, political corruption, incompetent institutions, bureaucracy, damage to the natural environment, the collapse of moral values, loss of faith, loss of faith and lack of understanding of the above problems.

Analysts of modern international relations have tended to expand the catalogues of global problems. This was surely caused by the ongoing processes of globalization, which has made local phenomena visible in various regions of the world, where they produced economic, political and social outcomes. "Social relations of worldwide range [intensified] binding various localities by the fact that local events are shaped by events that occur many thousands miles away and influence them in return" (Giddens, 1990: 64 after: Golka, 2000: 94).

Consequently, the events that did not have a global character right after the Second World War ended, are currently treated as global problems or fundamental issues. The clearest classification of global problems which is most congruent with the reality of the early $21^{\text {st }}$ century is that developed by the experts at the World Bank in 2006. Detailed problems were identified within five thematic areas (Bhargava, 2006: 3). In the thematic area of "global economy" the problems of international trade, financial stability, poverty and inequality, debt relief, international migration, food security, and intellectual property rights were indicated. In the thematic area of "Global human development" the problems of communicable diseases, humanitarian emergencies, hunger and malnutrition and refugeeism were defined. The thematic area "Global environment and natural resources" was connected to problems with climate change, deforestation, access to safe water, loss of biodiversity, land degradation, depletion of fisheries and the sustainable energy question. In the "Peace and security" thematic area the problems of arms proliferation, armed conflicts, terrorism, "drug trafficking and other crime," disarmament and genocide were defined. The thematic area entitled "Global governance" focused on such challenges as conflict prevention, reform of the UN system and international financial institutions, enforcement of international law, human rights, as well as implementation of multilateral treaties (ibidem). 
Apart from various classifications, global problems (in line with the above considerations) should be considered as phenomena that concern all of humanity and occur on a worldwide scale, and which are simultaneously perceived as threats to the international community and its individual members, as well as challenges that can only be solved by means of international cooperation. Taking into consideration the characteristics of global problems indicated above, the phenomenon of migration (both voluntary and involuntary) and the question of refugees should be included among global problems.

Although migration has occurred since ancient times, it has definitely intensified over the last sixty years (the number of migrants has doubled over the last 25-30 years). The UN estimated that in the period 1960-1965, for various reasons, approximately 76 million people remained outside their states of origin for more than one year. In 1970, their number went up to 81 million to reach 84 million five years later. Nearly 100 million migrants were recorded in 1980, their number increased to 105 million in 1985 , to 154 million in 1990, and 175 million in 2000. The number of migrants was estimated at 214 million in 2010, and at 232 million in 2013 (World, 2004: tab. II. 1; Trends, 2013).

A relatively small part of these numbers is constituted by individuals seeking protection against persecution. When organized activities commenced in 1921 in order to eliminate the phenomenon of refugeeism the number of refugees was estimated at 1-1.5 million. In 1951, approximately 1 million people who left their places of residence for fear of persecution, and nearly 1 million Palestinian refugees, needed international protection. Around 3 million people sought protection and aid in various locations in the period 1965-1975, there were 8 million of them in 1985 and around 13 million in 1990-2001. In 2008, the number of people forced to leave their places of residence for fear of persecution exceeded 30 million. In 2010, their number was estimated at 36.4 million and in January 2013 at 35.8 million ("Refugees" 1998: 12; UNHCR by numbers 1999, 1999: 3; Refugees by numbers 2002, 2002: 2; Measuring Protection, 2008: 1; UNHCR Global Report, 2010: 151; UNHCR Global Trends, 2013: $2,46)$. These numbers need to be supplemented by the figures for Palestinian refugees, amounting to half a million in 1950,1.8 million in 1980 and nearly 2.5 million ten years later. There were 3.7 million Palestinian refugees in 2000. Their number went up to 4.8 million in 2010 and reached 4.9 million in 2013 (Annual, 1956; UNRWA in figures, 2010; UNRWA in figures, 2013).

The universal character of refugeeism is not only the result of its intensification and constant increase in the number of people forced to leave their home and seek protection in other states or regions. Refugeeism is perceived as an international global problem, also due to the fact that this kind of coerced relocation of people occurs between territories or states located in different regions of the world, states at different levels of economic and civilizational development, states with different cultures and different historical or political characteristics. The question of refugees is therefore a phenomenon that has a universal global influence. It can occur at any time, in any region of the world, and its outcomes can be observed thousands of kilometers away (such as current events in Syria and the Central African Republic which result in new waeves of refugees have repercussions in neighboring states, as well as in Europe, Australia and the United States). 
For all these reasons, the question of refugees "needs to be treated globally and by all states [...] in terms of an international strategy" (Widgren, 1989: 49-50). This is the third feature which makes the question of refugees an international global problem. It is impossible for individual states to solve it. It calls for the coordination of efforts and joint activities of all members of the international community. The perception of this problem has thus evolved from the stage where states did not act to solve this problem to a period where organized activities at the national, regional and universal level commenced with respect to this phenomenon. It was decided that cooperation to solve the problem of refugeeism needs to be effected not only by the states of origin and receiving states, but first and foremost it needs to be implemented by international governmental and non-governmental organizations. The activities initiated as consequences of having become interested in the problem, have been a result of its dual perception: as a challenge that needs to be met on the one hand, and as a threat that needs to be counteracted and eliminated on the other. This dual perception characterizes both states and other members of the international community as well as individuals being refugees. The negative outcomes experienced by states of origin are reflected in the outflow of human capital, sometimes in a dramatic change in social, national and ethnic structure. As concerns receiving states, the adverse effects concern altered social, national and ethnic structures that may result in internal destabilization as well as the threat to the security of these states due to worsening relations with the states of origin. The threat to security as an adverse outcome of refugeeism occurs also at a regional and global scale. The adverse outcomes of refugeeism occur also at an individual level of the persons affected by this problem who are justifiably concerned about their own life and the lives of their loved ones.

The phenomenon of refugeeism, considered as one of the current global problems, has led the international community to realize that the activities of individual states are not going to solve this problem. It has also been recognized that the problem will not be solved by the bilateral cooperation of neighboring countries, the more so as such cooperation between the state of origin and receiving states is frequently not possible. This, in turn, has resulted in the conviction that the activity of individual states needs to be complemented by the activities undertaken by international organizations. At the same time, it was stressed that the question of refugees should be perceived both in terms of the protection of human rights and in relation to the fundamental objectives of the international community, namely ensuring peace and security. As it was concluded: "We will not enjoy development without security, we will not enjoy security without development, and we will not enyoy either without respect for human rights" (In Larger Freedom, 2005: para. 17). Modern refugee crises (such as those in Syria and the Central African Republic) and their adverse impact on the situation of individuals, as well as the security of different regions, confirmed that these conclusions were justified. At the same time, these crises demonstrate how difficult it is for different states and international organizations to cooperate and consequently solve the international global problem of refugees. 


\section{Bibligraphy}

Adamczyk A. (2012), Społeczno-polityczne implikacje imigracji do Polski w latach 1989-2007, Poznań.

Anioł W. (1985), Zależności globalne a stosunki międzynarodowe, "Sprawy Międzynarodowe”, No. 1.

Annual Report of the Director of the United Nations Relief and Works Agency for Palestine Refugees in the Near East, Covering the period 1.07.1955 to 30.06.1956 (1956), GA/11/Supplement No. 14 (A/3212), New York.

Bhargava V. (2006), Introduction to Global Issues, in: Global issues for global citizens. An introduction to key development challenges, (ed.) V. Bhargava, Washington.

Botkin J. W., Elmandjra M., Malitza M. (1979), No Limits to Learning. Bridging the Human Gap. A Report to Club of Rome, New York.

Castels S., Miller M. J. (2011), Migracje we współczesnym świecie, Warszawa.

Cesarz Z. (2002), Problemy globalne wspótczesności, in: Z. Cesarz, E. Stadtmüller, Problemy polityczne wspótczesnego świata, Wrocław.

Common Security. A Programme for Disarmement. The Report of the Independent Commission on Disarmament and Security Issues under the Chairmanship of Olof Palme (1982), O. Palme et al., London.

Giddens A. (1990), The Consequences of Modernity, Cambridge.

Goals for mankind. A Report to the Club of Rome on the New Horizons of the Global Community (1977), E. Laszlo et al., New York.

Golka M. (2000), Czy globalizacja jest globalna?, in: Europa Środkowo-Wschodnia a globalizacja, (ed.) T. Wallas, Poznań.

In Larger Freedom: Towards Development, Security and Human Rights for All. Report of the UN Secretary-General (2005), UN Doc A/59/2005, 21.03.2005.

Introduction to the Annual Report of the Secretary-General on the Work of the Organization (1969), General Assembly Official Records: Twenty-Fourth Session, Supplement No. 1A (A/7601/Add. 1), New York.

Jończy R. (2003), Migracje zarobkowe ludności autochtonicznej z województwa opolskiego. Studium ekonomicznych determinant $i$ konsekwencji, Opole.

Kersten K. (1996), Przymusowe przesiedlenia ludności - próba typologii, in: Utracona Ojczyzna. Przymusowe wysiedlenia, deportacje i przesiedlenia jako wspólne doświadczenie, (eds.) H. Orłowski, A. Sakson, Poznań.

Knopek J. (2008), Migracje międzynarodowe jako przedmiot badań politologicznych, in: Procesy migracyjne: teoria, ewolucja $i$ współczesność, (eds.) L. Kacprzak, J. Knopek, Piła.

Kraszewski P. (2003), Typologia migracji, in: Migracja - Europa - Polska, (eds.) W. J. Burszta, J. Serwański, Poznań.

Kulisher E. (1948), Europe on the Move: War and Population Changes 1917-1947, New York.

Lee E. S. (1966), Theory of Migration, "Demography", Vol. 3, No. 1.

Maryański A. (1984), Migracje w świecie, Warszawa.

Massey D. S., Arango J., Hugo G., Kouaouci A., Pellegrino A., Taylor J. E. (1993), Theories of International Migration: A Review and Appraisal, "Population and Development Review", Vol. 19, No. 3.

Meadows D. H., Meadows D. I., Randers J., Behrens III W. W. (1972), The Limits to Growth. A Report for the Club of Rome's Project on the Predicament of Mankind, New York. 
Measuring Protection by numbers 2008 (2008), Geneva.

Mojsiewicz Cz. (2003), Świat, w którym żyjemy, Poznań.

Niedźwiedzki D. (2010), Migracje i tożsamość. Od teorii do analizy przypadku, Kraków.

North-South: A Programme for Survival. The Report of the Independent Commission on International Development Issues under the Chairmanship of Willy Brandt (1980), W. Brandt et al., London.

Our Common Future: From One Earth to One World. Report of the World Commission on Environment and Development (1987), G. H. Brundtland et al., New York.

Peccei A. (1994), The Club of Rome: Agenda for the End of the Century, Rome, 8-13 March 1984, "Proceedings", Series 1, No. 9.

Petersen W. (1958), A General Typology of Migration, "American Sociological Review”, Vol. 23, No. 3, available at JSTOR, http://www.jstor.org, 23.01.2013.

Ravenstein E. G. (1885), The Laws of Migration, "Journal of the Royal Statistical Society of London", Vol. 48, No. 2, available at: JSTOR, http://www.jstor.org, 26.01.2013.

"Refugees" (1998), No. 111.

Refugees by numbers 2002 (2002), Geneva.

Report of the Secretary-General on the Work of the Organization (1983), General Assembly Official Records: Thirty-Eight Session, Supplement No. 1 (A/38/1), New York.

Sakson A. (2008), Migracje - fenomen XX i XXI wieku, "Przegląd Zachodni”, No. 2.

Stark O., Bloom D. E. (1985), The New Economics of Labor Migration, "AEA Papers and Proceedings", Vol. 75, No. 2.

Stouffer S. A. (1940), Intervening Opportunities: A Theory Relating Mobility and Distance, "American Sociological Review", Vol. 5, No. 6, available at JSTOR, http://www.jstor.org, 26.01.2013.

Tinbergen J. (1976), Reshaping the International Order. A Report to the Club of Rome, New York.

Trends in International Migrant Stock (2013), United Nations Department of Economic and Social Affairs, Population Division, http://www.esa.un.org, 7.02.2013.

UNDESA - International Migration 2013, United Nations Department of Economic and Social Affairs, Population Division, http://www.esa.un.org, 29.10.2013.

UNHCR by numbers 1999 (1999), Geneva.

UNHCR Global Report 2009 (2010), Geneva.

UNHCR Global Trends 2012 (2013), Geneva.

UNRWA in figures as of 30 June 2010 (2010), UNRWA Public Information Office, Gaza.

UNRWA in figures as of 30 June 2013 (2013), UNRWA Public Information Office, Gaza.

Widgren J. (1989), Europe and International Migration in the Future. The Necessity for Merging Migration, Refugee and Development Policies, in: Refugees and International Relations, (eds.) G. Loescher, L. Monahan, Oxford.

World Economic and Social Survey 2004: International Migration (2004), United Nations Department of Economic and Social Affairs, New York.

\section{ABSTRACT}

The problem of refugees is a phenomenon characteristic of contemporary international relations. It can take an individual form (as a result of individual persecutions of a racial, religious, 
national or political character) or the form of mass relocations, especially in the face of military conflicts or general breaching of human rights. The purpose of this paper is to present the refugee question as an international global problem that may appear in any region of the world, impacting the situation of states and societies, that is perceived as both a threat and a fundamental challenge for the entire international community.

\section{UCHODŹSTWO JAKO MIĘDZYNARODOWY PROBLEM GLOBALNY}

\section{STRESZCZENIE}

Uchodźstwo jest fenomenem charakterystycznym dla współczesnych stosunków międzynarodowych. Może przyjąć postać indywidualną (będąc efektem prześladowań o charakterze rasowym, religijnym, narodowościowym czy politycznym), ale także postać przemieszczeń masowych, powodowanych konfliktami zbrojnymi czy powszechnymi naruszeniami praw człowieka. W artykule ukazano zjawisko uchodźstwa jako międzynarodowy problem globalny, który może pojawić się w każdym rejonie świata, a postrzegany jest zarówno jako zagrożenie, jak i fundamentalne wyzwanie dla całej społeczności międzynarodowej. 